\title{
Catechin-rich green tea extract increases the expression of genes of the cholesterol synthetic pathways in livers of normal diet- and high-fat diet-fed rats
}

\author{
Toshikazu Suzuki ${ }^{1,2 *}$, Mayumi Nagata², Ayumi Takagi ${ }^{1}$ \\ From Metabolism, Diet and Disease 2014: Cancer and metabolism \\ Washington DC, USA. 28-30 May 2014
}

\section{Background}

In vivo studies using rodents have shown that green tea extract (GT) and catechins isolated from green tea can induce a variety of health effects, including antiobesity, hypoglycemic and hypolipidemic activities. However, we and others observed that serum cholesterol levels were increased by GT and tea catechins in rats and mice [1]. In this study, we examined whether dietary GT affects the expression of genes involved in cholesterol synthesis.

\section{Materials and methods}

Catechin-rich (30\% catechin) GT was used for the in vivo studies. Male Sprague-Dawley rats (average weight $237.7 \mathrm{~g}$ ) were divided into six groups. The first group was fed a normal diet (ND, 10\% calories from fat); the second group a high-fat diet (HFD, $40 \%$ calories from fat); the third group a ND containing $1 \%$ GT (ND + 1\% GT); the fourth group a HFD + $1 \%$ GT; the fifth group a ND $+3 \%$ GT; and the sixth group a HFD $+3 \%$ GT. After 4 weeks of feeding, rats were euthanized by whole blood collection under anesthesia. Serum metabolites were determined using a dry chemistry analyzer. Total RNA samples extracted from the liver were used for microarray and quantitative real-time PCR (qPCR) analyses. Hepatic lipids were extracted with chloroform-methanol 2:1, and liver triglyceride (TG) and cholesterol (Cho) levels were determined.

'Department of Health and Nutrition, Wayo Women's University, Ichikawa, Chiba, Japan

Full list of author information is available at the end of the article

\section{Results}

As reported previously, GT increased the serum levels of total cholesterol (T-Cho) and high-density lipoprotein cholesterol (HDL-Cho) in a concentration-dependent manner in both ND- and HFD-fed rats. Conversely, GT lowered hepatic TG and T-cho levels. Microarray analysis data suggested that GT increased more than two-fold the mRNA expression of nine hepatic genes involved in cholesterol synthesis out of 21 analyzed in ND-fed rats. qPCR analysis revealed that GT significantly increased the mRNA levels of six genes involved in cholesterol synthesis in ND-fed rats. Similar but smaller effects of GT also were observed in HFD-fed rats.

\section{Conclusions}

The results suggested that GT increased serum cholesterol levels, at least in part, through the increased expression of genes in the cholesterol synthetic pathways in the liver. GT also increased the mRNA levels of Srebf2 and Insig1, which are positively regulated by SREBP2. Therefore, dietary GT may increase expression of these genes by SREBP2 activation.

\footnotetext{
Authors' details

'Department of Health and Nutrition, Wayo Women's University, Ichikawa, Chiba, Japan. ${ }^{2}$ Graduate School of Human Ecology, Wayo Women's University, Ichikawa, Chiba, Japan.

Published: 28 May 2014

Reference

1. Suzuki T, Takagi A, Takahashi M: Catechin-rich green tea extract increases serum cholesterol levels in normal diet- and high fat diet-fed rats. BMC Proc 2012, 6(Suppl3):P47.
} 
doi:10.1186/2049-3002-2-S1-P71

Cite this article as: Suzuki et al:: Catechin-rich green tea extract

increases the expression of genes of the cholesterol synthetic pathways

in livers of normal diet- and high-fat diet-fed rats. Cancer \& Metabolism

2014 2(Suppl 1):P71.

Submit your next manuscript to BioMed Central and take full advantage of:

- Convenient online submission

- Thorough peer review

- No space constraints or color figure charges

- Immediate publication on acceptance

- Inclusion in PubMed, CAS, Scopus and Google Scholar

- Research which is freely available for redistribution

Submit your manuscript at 